Article

\title{
Staying the Course: Collaborative Modeling to Support Adaptive and Resilient Water Resource Governance in the Inland Northwest
}

\author{
Allyson Beall King * and Melanie Thornton \\ School of the Environment, Washington State University, Pullman, WA 99164-2812, USA; \\ melanie.thornton@wsu.edu \\ * Correspondence: abeall@wsu.edu; Tel.: +1-509-335-4037
}

Academic Editors: Sharon B. Megdal, Susanna Eden and Eylon Shamir

Received: 22 February 2016; Accepted: 18 May 2016; Published: 31 May 2016

\begin{abstract}
Water resource governance, much like the systems it endeavors to manage, must be resilient and adaptive. Effective, resilient and adaptive water resource governance requires continuing stakeholder engagement to address the complex nature of human and natural systems. Engagement is an adaptive and iterative process of education and empowerment, building relationships and trust, and facilitating collaboration. Collaborative modeling is a methodology that integrates diverse stakeholder perspectives, fosters discussions, and creates space for problem identification and consensus-based strategies and solutions to current water resource challenges. We define collaborative modeling broadly, such that it includes a wide range of systems thinking exercises, as well as dynamic models. By focusing on the relationships and interconnections in the system, collaborative modeling facilitates clarification of mental models and the communication of science. We will describe our work in two interstate basins and how it has evolved over time as these basins strive to develop collaborative governance, and find solutions for their water resource challenges.
\end{abstract}

Keywords: collaborative modeling; integrated water resource management; systems thinking; stakeholder engagement; public participation

\section{Introduction}

Water resource governance, much like the systems it endeavors to manage must be adaptive and resilient. Resilient refers to the capacity of the socio-ecological system to absorb disturbance and reorganize while undergoing change so as to still retain essentially the same function, structure, identity, and feedbacks [1]. We use the term adaptive to describe an approach that adjusts in response to emerging knowledge and has the capacity to support system resilience [1,2]. The foundations for adaptive and resilient management are rooted in the social, legal and scientific recognition that it is crucial to integrate the values and worldviews of diverse stakeholders into decision processes for resource management that utilizes best available science [3-5]. These decision processes must be iterative, ongoing, and capable of dealing with scientific uncertainty within a constantly changing social and biophysical system.

We are in the Anthropocene [6]; human impacts are now the dominant driver of global change creating ever more complex environmental conditions that impact both ecosystem and human health. In the 1960s and 1970s, the United States developed policies and laws, such as the National Environmental Policy Act (NEPA), the Clean Air Act (CAA), the Clean Water Act (CWA) and the Endangered Species Act (ESA), which endeavor to assess risk and protect the environment while, at the same time, consider the economic and social needs of the nation's human population [7-10]. Indeed, the NEPA purpose statement declares that it is "a national policy which will encourage productive 
and enjoyable harmony between man and his environment" [7]. This foundation of policy and law has helped mitigate problems, such as point source pollution; however, managing complex and cross jurisdiction environmental challenges related to climate change impacts, non-point source pollution and other ecosystem service tragedies of the commons [11] are still, if not more problematic today.

Policies, such as NEPA, and laws, such as the CWA, CAA, and ESA, were passed in response to anthropogenic environmental degradation and in recognition of "the critical importance of restoring and maintaining environmental quality" [7]. Years of case law have defined the roles and responsibilities of national and state agencies and the manner in which these agencies integrate science into management. The scientific approaches that have been adopted require social involvement in the problem-identification and solution-producing process such that decision development is transparent and respectful of social needs and diverse world-views [12-15]. The society-science nexus is so completely intertwined that "neither science nor democracy can enhance human welfare in the absence of the other" [16] (p. xiii). With respect to science, the field of ecosystem ecology contributes to an understanding that humans are integral parts of all ecosystems, and that ecosystems and our knowledge of them change over time. Natural resource management has adopted adaptive management as a theoretical framework to manage systems for which scientific knowledge is provisional. It tells us that we should learn by monitoring the results of scientifically designed management plans and then adjust accordingly [17]. It builds on key premises which include: (1) significant connections need to be determined; (2) structural features are more important to measure than numbers; (3) changes in one variable can have unexpected impacts; (4) monitoring of one variable can seem to indicate no change when drastic change is imminent $[2,12,18]$. To adaptively manage a system, we must acknowledge uncertainty, surprise, and the dynamic variability and intricate feedbacks that are inherent to both the system and to its dynamics [19]. Integrating the concept of resilience into this framework encourages us to manage for function and structure such that the ecosystem services upon which we are reliant are available for both current and future generations [20]. Finally, adaptive and resilient management of bio-physical systems occurs within dynamic social systems that are governed by historical context, diverse values and worldviews.

Water resource management in the United States has evolved from what was initially concerned only with the delivery of sufficient quantity and quality. This traditional approach has been largely supplanted by Integrated Water Resource Management (IWRM), that strives to integrate quantity, quality, surface and groundwater dynamics, as well as ecosystem services into an adaptive, resilient governance framework that is capable of spanning jurisdictional boundaries [21]. Hydrologic systems have multiple actors and entities involved in management decisions and legacy issues such as appropriated water rights and instream infrastructures. Making decisions within the complexity of IWRM requires that people involved in water resource governance span boundaries that may be institutional, cultural, spatial and or temporal, and it requires viewing the social-ecological-hydrological system as dynamic rather than linear [22]. Furthermore, IWRM necessitates bridging the gaps between water resource science and multi-jurisdictional decision making $[23,24]$.

Models and modeling processes have long been recognized as useful tools for integrating social, economic and environmental information to facilitate complex environmental management issues and decisions [12,25-31]. We describe "a model [as] a substitute for a real system" [32]. The model may be used for communication or for learning about how the system behaves over time. The model could be as simple as a picture, or a diagram. A model could be a physical representation of natural processes such as wind tunnel or stream table. A model could portray relationships through a causal loop diagram (CLD) that describes causation. A mathematical computer model can be used to simulate behavior of multiple parameters over time. These representations of reality may be used to communicate the perceptions of an individual or group of individuals, or they may be used to calculate physical processes, such as the flow of water, to help us understand how water moves across and through a landscape. The model building process begins with the creation of mental models. Mental models 
are representations of how an individual understands the surrounding world based on their own experiences [33-35]. These can be "deeply ingrained assumptions, generalizations, or even pictures or images [that] influence how we understand the world around us, and how we take action" [34]. We communicate mental models with language and images. Communicating and analyzing our understanding of system complexity may also require the use of systems thinking tools such as causal loop diagrams that describe relationships and causation [34,36]. While mental models may serve us well as we conduct our daily lives, and systems thinking may help us see the complex relationships around us, calculating the relationships between multiple parameters and the feedbacks between these parameters simultaneously and over time requires the use of computers $[27,32,36,37]$. Computer models that integrate social, economic and environmental information are effective for synthesizing scientific research and decision making [25,30,37-40]. Building models in collaborative social processes that include hydrologic experts and local stakeholders enables transparency and salience, and helps bridge the gap between science and water resource management $[12,31,37,39,41-49]$. Best practices for creating such models include involving stakeholders early and often in the model building process $[37,41,43]$.

Collaborative modeling $(\mathrm{CM})$ is a methodology that integrates diverse stakeholder perspectives, fosters discussions, and creates space for problem identification and the production of consensus-based, scientifically sound management strategies. Balancing the need for dynamic solutions while maintaining respect for values creates space for exploration and innovation that is served by the tension between what was or is and what could be. As stakeholder groups negotiate the 'problem to solution' space, CM facilitators seek to transition people away from linear thinking and conflicts that are often the result of entrenched value systems or worldviews [42-44,48]. While conflict can progress in an unproductive manner, and create unfavorable outcomes it is important to note that conflict, in of itself is not necessarily bad. Conflict has the potential to drive needed change and without the potential for conflict people may not be motivated to adapt their system in advance of crisis. This paper will describe the use of CM as a methodology that provides the opportunity for people to visualize possible futures and reflect on which possibilities are favorable and which are undesirable in advance of potential conflict. The gap between favorable and undesirable futures creates tension that provides impetus for change, innovation, and creativity. We will refer to this type of tension as creative tension [34]. It is through the process of engaging in this state of "creative tension" that resilient and adaptive solutions arise [34].

In this paper, we describe experiences from two collaborative modeling processes that integrate stakeholder engagement, systems thinking and system dynamics, the disciplines of water and natural resource modeling, and resource planning methodologies. For the purposes of this research, we define stakeholders broadly. Participants in our CM processes include water resource professionals involved in decision-making, local and state agency personnel, purveyors, consultants, NGOs, legal experts, elected officials, academic researchers and self-selected members of the general public who are interested in water resource management. These CM processes have occurred within the inland Northwest, in the Palouse basin and the Spokane basin. Both basins are bi-state and straddle the Idaho and Washington border. We will describe our work in these basins and how it has evolved over time as stakeholders strive to develop collaborative governance for adaptive and resilient water resource management.

\section{Palouse and Spokane Basins: The People and the Basins}

We are continuing to engage stakeholders in two interstate basins in the inland Northwest, the Palouse and Spokane basin. Both basins are designated as sole source aquifer systems [50-52]. The Palouse basin and Spokane River-Spokane Valley Rathdrum Prairie Aquifer basin have from many perspectives an abundance of water. Despite the apparent abundance of freshwater, system leaders in the region understand the importance of institutionalizing resilient and adaptive management in advance of a potential water management crisis. They seek to institutionalize collaboration, and to 
utilize the creative tension that the potential for conflict creates, as well as facilitate the communication of science and education and outreach through annual water summits or forums. In the Palouse and Spokane basins, system leaders invited collaborative modelers to work with diverse regional stakeholders to help people move out of entrenched mental models through systems thinking exercises, the development of computer models, and involvement in annual summits and forums. It is hoped that this early and iterative engagement with collaborative modeling will serve to prevent unproductive conflict over water resources in the future. System leaders sought the involvement of collaborative modelers at Washington State University to assist basin stakeholders as they plan for the unthinkable. It was in this context that a facilitated collaborative modeling process was implemented beginning in 2008 in the Palouse and in 2010 in the Spokane basin.

In the Palouse basin, there has been growing concern over water supply and declining well levels, which is compounded by the scientific uncertainty related to total supply and potential for recharge. In the late 1980s, stakeholders from the Palouse Basin Aquifer Committee, including major groundwater pumpers, developed a groundwater management plan, that when combined with engineering and technology has effectively kept demand steady at 1990s levels, in spite of an average population growth rate of one percent [53]. Rates of decline in wells have decreased since the late 1980s, however scientific explanation for this behavior is still primarily in the form of hypotheses [50,53,54]. Research to explain well behavior, aquifer storage, flow and potential for recharge is ongoing, yet it is limited by complex hydrogeology, the number of monitoring wells, and limited fire suppression storage that restricts the length of pump tests. Although there is significant concern about declining well levels at current rates of growth, the water supply will likely last decades. In the near term, conflict in this basin will likely not arise from a limited supply but rather from differing social values for the resource, development, and conservation. The potential for conflict as well as the need for sustainable long-term thinking led to our involvement [53]. We began our work in the Palouse in 2008 with a collaborative model building process that resulted in a web based simulation model for education and outreach [53]; it has progressed with the development of systems thinking exercises at the annual water summit. To contrast, the Palouse basin has a fossil water supply that will slowly be compromised by development while the Spokane basin has a highly dynamic resource in what has historically been a snow-dominated basin [55].

Our work began in the Spokane basin in 2010 with system thinking and mental model assessment exercises; we then added a simulation model-building component in 2013. The process was first initiated during our National Science Foundation Water, Sustainability and Climate planning grant in 2010, and then expanded as a part of Watershed Integrated System Dynamics Modeling (WISDM), a Water, Sustainability and Climate grant funded by National Institute for Food and Agriculture. The goal of our contribution to WISDM was to develop a collaborative modeling methodology to better understand how and when institutions change. In 2009, the Spokane basin finished a 10 year long, contentious total maximum daily load (TMDL) process for phosphorous and dissolved oxygen levels in the Spokane River. People were tired of hearing about phosphorous, tired of conflict and still feeling bruised from compromise and the process in general. Although there was a sense of accomplishment, relationships were fragile. We were invited to help facilitate continued collaboration that would help maintain and advance cooperation until the next big issue needed to be addressed [56]. In addition, hydrologic experts are concerned about the lay perception that the "basin has abundant water" and that "talk of water conservation is bad for business" [56,57], even though there is evidence that the basin is vulnerable to climate change [55,58].

\subsection{The Palouse Basin: Issues and Hydrology}

The Palouse basin aquifer system supports approximately 50,000 residents and includes the cities of Moscow and Pullman, and two research universities, University of Idaho (UI) and Washington State University (WSU). The two cities and two universities, collectively known as the four "big pumpers" provide the bulk of supply for the basin. The basin has a strong agricultural base, however it is 
primarily dry land farming with very limited irrigated agriculture. Baseline indoor use across the basin is about 90 gallons per person per day, while total use averaged over the year is about 120 gallons per person per day. Weather has a significant impact on summer pumping in the inland Northwest, where there is little summer rainfall. The aquifer system is comprised of two heterogeneous basalt aquifers named for their respective geologic formations. The upper aquifer called the Wanapum has limited recharge; the deeper, much larger Grande Ronde aquifer is confined, contains fossil water and has little evidence of recharge on time scales relevant to resource management $[50,53,54]$. The Wanapum, primarily used by the City of Moscow, exhibited sharply declining well levels through the 1960s at which time Moscow added additional wells into the Grande Ronde. Wanapum wells now sustainably support about 6000 people [53]. Concern over declining well levels also led Moscow to add a reuse plant for irrigating landscape at the UI in 1976. Basin wide water demand on the Grande Ronde has increased seven fold since the 1930s, and although decline in water levels do not follow demand in a linear manner, there is nevertheless concern over unsustainable use.

\subsection{The Spokane Basin: Issues and Hydrology}

To the north of the Palouse basin in a very different geologic system is the Spokane River basin and the Spokane Valley Rathdrum Prairie (SVRP) aquifer. The Spokane River Basin covers roughly 2400 square miles. While the headwaters lie in the Northern Rockies, the Spokane River begins at the outlet of Coeur d'Alene Lake in Idaho and flows westward, crossing the border into Washington 10 miles downstream then a flowing an additional 110 miles to its confluence with the Columbia River. The river is used for fishing, swimming, boating and hydropower. The river also provides aquatic, riparian and upland habitat for an assortment of species. The Spokane River interacts with the Spokane Valley Rathdrum Prairie (SVRP) aquifer, a sole source aquifer for over 600,000 people that is utilized for domestic, irrigation, and industrial water [52]. The SVRP aquifer is an unconfined aquifer composed of unconsolidated coarse-grained sand, gravel, cobbles and boulders deposited by the series of catastrophic glacial floods with hydraulic conductivity estimates ranging from 100 to $6200 \mathrm{ft}$./day, with most values larger than $1000 \mathrm{ft}$./day [59]. The SVRP and the Spokane River interact at rates upwards of millions of gallons per day, with losing and gaining reaches throughout the basin floor [52,60]. This river basin has experienced low flow conditions on the Washington side of the border that has resulted in a Low Flow Rule [61], phosphorous loading from sources in both Washington and Idaho resulting in a Total Maximum Daily Load (TMDL) rule for phosphorous and dissolved oxygen on the Spokane River [62], metals contamination from mining, polychlorobiphenyl (PCB) contamination, and multiple jurisdictions involved in management. While these issues may appear extensive, there has been a significant improvement in water quality since the 1950s, and local stakeholders describe the basin as providing them with a high quality of life. Aside from the arduous phosphorous-dissolved oxygen TMDL process that culminated in 2010, there is relatively low conflict over water due in part to the abundant supply.

After a description of collaborative modeling we will describe our collaborative modeling experience in each basin that includes exercises for systems thinking and mental model assessment, and the model building and simulation processes.

\section{The Breadth and Depth of Collaborative Modeling}

Collaborative modeling is a methodology that helps us embrace adaptive theory while striving to holistically address the complexity of details concerning system behavior including feedback and time delays $[25,30,32,42,63]$. Collaborative modeling has foundations in group model building $[35,64,65]$ that utilizes systems thinking, model building and computer simulation. The process of building a collaborative model helps water resource stakeholders clarify their own mental models and gain a better understanding of the system as they are facilitated through the process of integrating technical, scientific information with local knowledge and expertise in a computer simulation model [37,39-49]. The CM process develops one or more types of systems models ranging from qualitative, descriptive 
visual maps or causal loop diagrams that seek to identify the archetype of behavior, to quantitative, spatial and or temporal modeling. CM processes can be used to mitigate conflict through gaming and roll playing, even having stakeholders represent the opposition in a simulation exercise [66]. Many practitioners have a preferred modeling platform for building models in methods for which they were trained or that work well with their own mental models of how the world works. The choice of models may be related to the problems people are trying to define and or solve, or by the needs and preferences of stakeholders. Costanza et al. describe the purpose of modeling building processes as ranging from scoping, to research, to management [40]. Specifically with respect to water resource management we see the purpose of this iterative process ranging from research and basic science, to education and outreach, and to planning and management of complex hydrologic systems. The development process is not linear but rather context and stakeholder specific.

We approach collaborative modeling from the perspective of the eight steps of model formation adapted from Beall and Ford, as depicted in Figure 1 [25]. Early stages of iterative research, problem development and or education and outreach activities may focus on problem familiarization using systems thinking exercises (Figure 1a). The development of simulation models focuses on extending the process to include policy and sensitivity analysis (Figure 1b). In both contexts iteration over time is necessary for the development of robust models that reflect system complexities. These exercises offer the opportunity for collaborators to explore the structure and behavior of a system and create space for reflection, exploration and discussion. Finally, the process of collaborative modeling creates opportunity to explore, challenge, iterate and advance mental models.
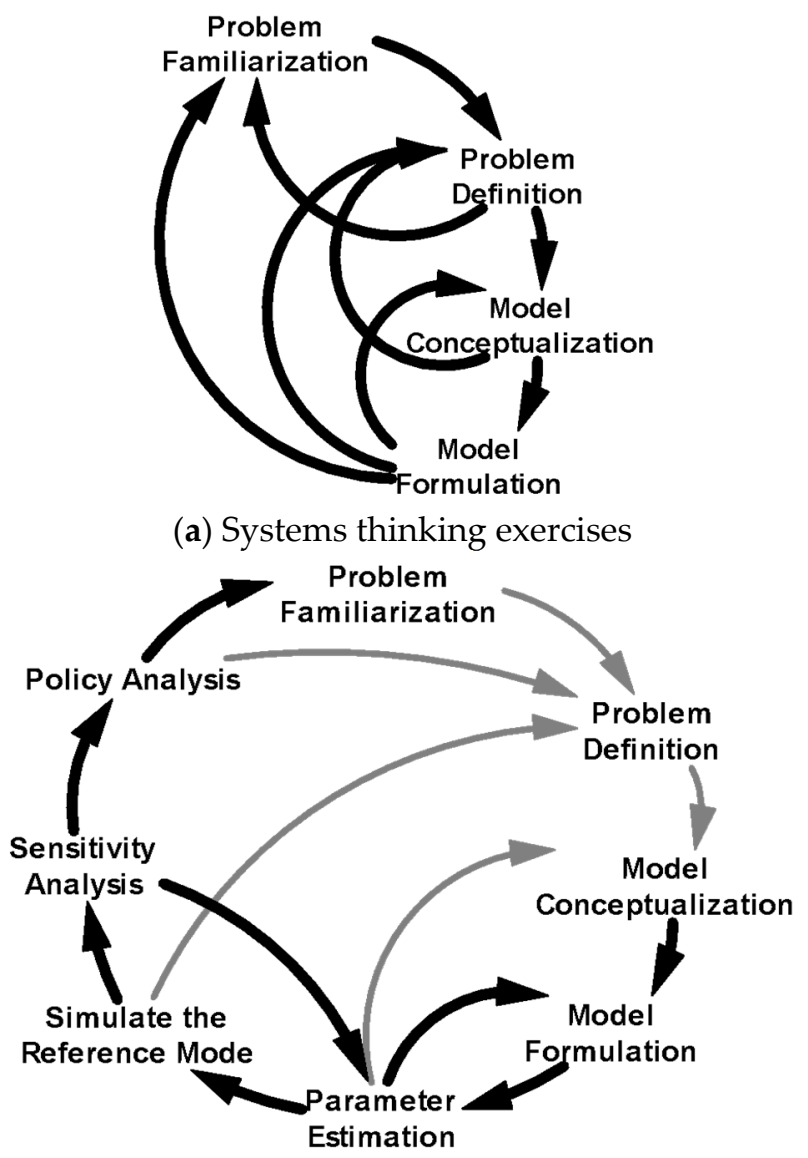

(b) Systems models for policy analysis

Figure 1. The eight steps of model building: (a) Iterative system thinking exercises for identifying and clarifying problems; (b) building simulation models expands the iterative process to include sensitivity analysis and policy analysis. Source: Beall and Ford [25]. 


\subsection{Iteration over Time and Collaboration}

We argue, as does Senge and others, that advancing mental models require iterative investment in systems thinking $[32,67,68]$. Systems thinking enables visualization of complexities, structure and feedbacks that cause behavior, and in so doing creates a more complete understanding of a system. While this mode of thinking is intuitive for some, for other individuals system thinking may require intentional and thoughtful practice, and a personal decision to value and invest in a more complete understanding of the system. Investing in systems thinking supports system resilience and the ability for self-sustaining adaptation over time because it helps us organize and evaluate uncertainty, surprise, dynamic variability, feedbacks and time delays. With respect to water resource management and who would benefit from such an investment, we consider the question: who are the decision makers in water resource management? Water use decisions are made at multiple spatial scales, ranging from large-scale hydropower and agricultural management, to individual indoor and outdoor residential water use. Therefore, we argue that all water users should be considered decision makers. Creating a suite of models relevant to the scope and scale at which decision makers operate can help bridge the gap between policy makers, resource managers, and end users. For example, collaboratively built education and outreach tools that simulate decisions made at the individual or household level highlight the impacts of individual water use behaviors on the system at large. Hydrologic models that simulate large-scale decisions may be used to illustrate the potential impacts of policies on individual users at a variety of scales. Collaborative modeling integrates multiple scales of water users into the decision development space, which improves transparency and the likelihood of politically acceptable water management outcomes [25,37,39-48].

Perceived problems and acceptable outcomes change over time, based on environmental factors including weather and climate, and social factors including cultural values and economics. Because concerns and management objectives change over time, long-term investment in systems thinking is an especially critical component of CM. Revisiting places, people and projects over time creates the opportunity for continuing discussion, education and outreach. A long-term process also facilitates model revision and iteration as new data and new knowledge develop. The act of revisiting may involve moving from systems thinking exercises for the stage of problem familiarization or definition (Figure 1a) to the stage of developing dynamic quantitative models (Figure 1b). Quantitative models are then iteratively expanded and improved. In some cases, the revisiting process helps participants iterate through a new problem familiarization loop. Invitations to return often come from system leaders in the communities who seek to create adaptive and resilient communities. These system leaders may work for industry, NGOs, city, county or state agencies. These individuals are invested in managing their systems over the long term, which often necessitates navigating a political environment characterized by regularly changing elected officials who may not have a sophisticated understanding of what 'long-term' water resource planning means [57]. As collaborative modelers, we emphasize the importance of sharing this long-term perspective, and share in the time commitment it takes for institutional, organizational and ecological change. Such change may be gradual or it may happen rapidly when the system reaches a tipping point or when a collective moment of realization and insight delivers inspiration.

The collaborative modeling process in the Palouse and Spokane basins includes an ongoing, iterative and flexible approach to stakeholder engagement and model building [25,69]. Engagement activities include systems thinking exercises, and model development that ranges from problem scoping, basic research, education and outreach, to planning and management. It is important to note that this was not a linear process, and our iterative approach varied in each basin, based on relevant stakeholder issues and needs. Table 1 lists our engagement activities and the years in which activities were performed in each basin. 
Table 1. Engagement activities over time in the Palouse and Spokane basins (2008 to 2016).

\begin{tabular}{|c|c|c|c|c|c|c|c|c|c|}
\hline Palouse Basin & 08 & 09 & 10 & 11 & 12 & 13 & 14 & 15 & 16 \\
\hline \multicolumn{10}{|c|}{ Systems Thinking } \\
\hline \multicolumn{10}{|l|}{ Meetings } \\
\hline \multicolumn{10}{|l|}{ CLD } \\
\hline \multicolumn{10}{|l|}{ Summit/clickers } \\
\hline \multicolumn{10}{|c|}{ Modeling and Simulation } \\
\hline \multicolumn{10}{|l|}{ Conceptualization } \\
\hline \multicolumn{10}{|l|}{ Formulation } \\
\hline \multicolumn{10}{|l|}{ Parameter Estimation } \\
\hline \multicolumn{10}{|l|}{ Model Simulation } \\
\hline \multicolumn{10}{|l|}{ Scenario Analysis } \\
\hline \multirow[t]{2}{*}{ Spokane River Basin } & 08 & 09 & 10 & 11 & 12 & 13 & 14 & 15 & 16 \\
\hline & & & $\mathrm{s} \mathrm{Tr}$ & & & & & & \\
\hline \multicolumn{10}{|l|}{ Meetings } \\
\hline \multicolumn{10}{|l|}{ CLD } \\
\hline \multicolumn{10}{|l|}{ Forum/clickers } \\
\hline & & & ing & ims & & & & & \\
\hline \multicolumn{10}{|l|}{ Conceptualization } \\
\hline \multicolumn{10}{|l|}{ Formulation } \\
\hline \multicolumn{10}{|l|}{ Parameter Estimation } \\
\hline Model Simulation & & & & & & & & & \\
\hline Scenario Analysis & & & & & & & & & \\
\hline
\end{tabular}

\subsection{Systems Thinking: Using Causal Loop Diagrams for Problem Identification}

Early stages of the CM process include systems thinking exercises to begin to clarify issues and to define the problem (Figure 1a). In the Palouse basin, the first several group meetings were dedicated to causal loop diagraming (CLD), while in the Spokane we utilized a group breakout session at the regional water conference to begin CLD. Participants were asked to work together to draw causal loop diagrams to conceptualize the subsystems of their regional human-natural system. They were asked to identify stocks, such as water in the aquifers or population living in the basin, and then they were asked to draw the stocks and describe connections between the stocks. We utilize CLD for multiple purposes for our systems thinking sessions. First, we use them to gain an understanding of the problems and issues as viewed by the participants. This is important so that we better understand the basin and can be equipped to build model simulations of important and relevant issues. CLD sessions are beneficial to participants because they help people view the basin broadly as an integrated socio-bio-physical system. Finally, the process facilitates discussion about mental models and promotes reflection about personal socio-scientific knowledge. In addition to CLD, participants were also asked to draw a timeline of the basin to facilitate discussion of how the basin had changed over time. In short, systems thinking exercises aim to help broaden participant's perspectives.

\subsection{Systems Thinking: Clickers and Mental Models}

We also utilize systems thinking exercises with broader audiences in each basin during annual regional water conferences that bring together local, state and federal agencies, elected officials and the public to share relevant water resource science and to discuss pertinent water resource challenges. These conferences are hosted by the Palouse Basin Water Summit and the Spokane River Forum, non-profit organizations founded at the request of basin stakeholders for the purpose of education and outreach, dissemination of science, and for talking about "all things related to water" [70,71]. Before each conference, we work with system leaders to develop multiple-choice questions about science, values and preferences, and management challenges. We are careful to use the iterative question development process as a transparent, trust building exercise. Questions are elicited from individuals and shared with a large group in advance of the conferences without identifying who posed the 
question. The group scrutinizes questions for clarity and to reduce the likelihood of controversial wording. During the conference, attendees are supplied with individual audience response technology, that we generically call clickers, to anonymously answer the questions [72]. The multiple-choice questions are imbedded in a power point presentation on a computer that receives information from each clicker. When a question is opened in the response system, participants are free to discuss the questions with one another before responding with their clickers. After the responses have been received, the cumulative responses are revealed instantly to the group. Depending on the type of question and level of discussion among participants, the session facilitator may leave the question open for any length of time. Questions related to science help participants learn about the resource when the correct answer is revealed. The number of correct answers helps facilitators, as well as participants, assesses the level of general knowledge. Questions related to values help the groups understand potentially diverse attitudes and preferences. Using clickers with multiple types of questions provides the opportunity to learn about individual and group mental models. The response system provides the opportunity to track how an individual operating the clicker that day answered all of the questions. Anonymity is preserved by random distribution of clickers as well as the size of the groups with whom we work. Over time and multiple conferences, we revisit specific questions of interest, revise questions to improve the educational experience, and design new questions as the basins adapt and or are faced with new challenges. These sessions provide the opportunity for people to learn about the resource, the values of others and they create space for reflection and discussion.

In the Palouse basin, system leaders hold an annual Water Summit for the local community as an opportunity to "continue the conversation about all things related to water in the basin" [70]. The gathering of approximately 200 people includes water resource managers from local and state agencies, elected officials and the public. Each year since 2013, we have been invited to facilitate clicker sessions. The invitation came after stakeholders in Spokane basin relayed their optimism about their own 2011 clicker experience to system leaders in the Palouse. We use clickers as an educational tool that assesses the level of knowledge about the aquifer system and well behavior. In addition, we use this opportunity to help this group of people better understand one another's mental models and preferences for resource management. These sessions are preceded by a state of the aquifer talk that includes well levels and rates of decline, changes in demand for the previous year, and weather conditions that impact demand. Clicker questions designed by stakeholders and answered anonymously include education, perceptions, values and policy preferences (Table 2).

In the Spokane River Basin, system leaders convene the Spokane River Forum every 12-18 months for water resource professionals to share information about their regional water resources. In fall 2010, we were invited to devise an interactive session at the May 2011 Spokane River Forum on the potential development of a PCB TMDL for the Spokane River. We spent several months in individual meetings with key stakeholders exploring perceptions, and formulating and screening a set of questions that we would present in May. We began by asking stakeholders what they would like to ask each other. Clicker questions designed by stakeholders and answered anonymously included preferences on a PCB TMDL. At subsequent Forums in 2012 and 2014, we have used this process to gauge the level of interest for collaborative bi-state water resource management. Similar to the session in the Palouse, at the 2012 Forum we also use this method to assess the level of the participants' hydrologic knowledge. At the conclusion of the 2012 Forum, we included questions that evaluated how well participants understood river-aquifer dynamics. Organizers were concerned that the audience did not perform well on the river-aquifer basics questions and perhaps left the conference with misinformation [56]. In response to this concern, at the 2014 event organizers began the Forum with "Hydrology 101", a plenary session on hydrology and hydrogeology basics presented with a panel of local hydrologic experts [56]. After a short explanation of correct answers attendees were guided to breakout sessions that would help explain complexities of basin hydrology. Table 3 provides a partial list of questions that were asked at the Forums between 2011 and 2014. 
Table 2. Partial list of clicker questions presented to participants at the Palouse Basin Water Summit between 2013 and 2015 (for additional questions please contact authors). Multiple-choice answer alternatives to six of these questions and the participant's responses are listed in Table 4.

\begin{tabular}{|c|c|}
\hline Clicker Question Category & Palouse Basin-Clicker Questions \\
\hline Education & $\begin{array}{l}\text { Pullman, WSU and UI utilize the Grande Ronde. Moscow uses both the } \\
\text { Grande Ronde and the Wanapum. How much of Moscow's water supply } \\
\text { comes from the Wanapum? } \\
\text { In the Palouse Basin what is the average per capita use per day averaged } \\
\text { over the year? }\end{array}$ \\
\hline Perceptions & $\begin{array}{l}\text { - What do you think is the primary reason that pumping rates have not } \\
\text { followed population growth? } \\
\text { Based on our current rates of use, how long do you think we can continue to } \\
\text { use the Grande Ronde? } \\
\text { - Rates of decline changing from } 1.5>0.9>0.6 \mathrm{ft} \text {. } / \text { year ... What does this } \\
\text { mean to you? } \\
\text { If the population growth rate increases to } 2 \% \text { across the basin will we be } \\
\text { able to maintain current pumping rates? }\end{array}$ \\
\hline Values & $\begin{array}{l}\text { - At what point would you consider water resources in the basin to be in a } \\
\text { critical situation? } \\
\text { Is it important to take a regional, collaborative approach among } \\
\text { governments, agencies and stakeholders to address water resource issues? } \\
\text { - As an individual water consumer on the Palouse what are you going to do } \\
\text { in the coming year? }\end{array}$ \\
\hline Preferences and Priorities & $\begin{array}{l}\text { - Where do you see water resource management in the Palouse Basin in } \\
20 \text { years? } \\
\text { - } \quad \text { Is the development of a surface water reservoir a priority? } \\
\text { - } \quad \text { Is the development of a reclaimed water plant in Pullman a priority? } \\
\text { Gould you prefer to have your water bill state volume of use based on } \\
\text { gallons per month or in cubic feet? }\end{array}$ \\
\hline
\end{tabular}

Table 3. Partial list of clicker questions presented to participants at the Spokane River Forum between 2011 and 2014 (for additional questions please contact authors). Multiple-choice answer alternatives to six of these questions and the participant's responses are listed in Table 5.

\begin{tabular}{|c|c|}
\hline Clicker Question Category & Spokane Basin-Clicker Questions \\
\hline Education & $\begin{array}{l}\text { - If flows at Post Falls Dam were increased during summer low-flow periods, } \\
\text { what would the result be? } \\
\text { The aquifer interacts with the Spokane River. In some places the river loses } \\
\text { water to the aquifer, in other places the river gains water from the aquifer. } \\
\text { How many gaining and losing reaches of the river are there? }\end{array}$ \\
\hline Perceptions & $\begin{array}{l}\text { - If WA Dept. of Ecology started developing a PCB TMDL today, how long do } \\
\text { you think it would take to complete? } \\
\text { - How much do you think a PCB TMDL would cost? } \\
\text { - Considering an estimated population growth rate of Washington }(\sim 3.88 \%) \\
\text { and Idaho }(\sim 2.3 \%) \text {, do purveyors currently own enough water rights to } \\
\text { meet user needs for the next thirty years? } \\
\text { - What do you think is the primary purpose of an instream flow rule? }\end{array}$ \\
\hline
\end{tabular}


Table 3. Cont

\begin{tabular}{|c|c|}
\hline Clicker Question Category & Spokane Basin-Clicker Questions \\
\hline Values & $\begin{array}{l}\text { - When do you predict there will be a surface water availability crisis in the } \\
\text { Spokane River Basin? } \\
\text { - When do you predict there will be a ground water availability crisis in the } \\
\text { Spokane River Basin? } \\
\text { Are you interested in learning more about bi-state water management } \\
\text { agreements used in the US? } \\
\text { What is your comfort level with a regional board/task force deciding where } \\
\text { PCB removal and reduction funding should be targeted? }\end{array}$ \\
\hline Preferences and Priorities & $\begin{array}{l}\text { - Where do you see management of water resources in the Spokane River } \\
\text { Basin in } 20 \text { years? } \\
\text { - Should establishing a plan for basin-wide water resources management be } \\
\text { a priority? } \\
\text { Do you consider PCBs unimportant, a WA issue, a ID issue or a } \\
\text { bi-state issue? } \\
\text { If a water supply crisis is imminent, which of these (1) infrastructure } \\
\text { measures and (2) behavior measures should we take to address it? }\end{array}$ \\
\hline
\end{tabular}

Table 4. Partial list of responses to clicker questions presented to participants at the Palouse Basin Water Summit (for additional questions please contact authors).

\begin{tabular}{|c|c|c|c|}
\hline $\begin{array}{l}\text { What do you think is the primary reason that pumping rates } \\
\text { have not followed population growth? }\end{array}$ & $\begin{array}{c}2013 \\
n=100\end{array}$ & $\begin{array}{c}2014 \\
n=100\end{array}$ & $\begin{array}{c}2015 \\
n=100\end{array}$ \\
\hline Changes in human behavior & $5 \%$ & $15 \%$ & $3 \%$ \\
\hline Changes in engineering and infrastructure & $20 \%$ & $20 \%$ & $9 \%$ \\
\hline A mix of the above answers & $75 \%$ & $65 \%$ & $86 \%$ \\
\hline I don't know & $0 \%$ & $0 \%$ & $3 \%$ \\
\hline Where do you see water resource management in the Palouse & 2013 & 2014 & 2015 \\
\hline Basin in 20 years? & $n=100$ & $n=100$ & $n=100$ \\
\hline Increased "collaboration and cooperation" & $42 \%$ & $52 \%$ & $56 \%$ \\
\hline Formal bi-state agreement" & $24 \%$ & $30 \%$ & $23 \%$ \\
\hline "Business as usual" & $18 \%$ & $9 \%$ & $4 \%$ \\
\hline "Increased conflict" & $15 \%$ & $10 \%$ & $16 \%$ \\
\hline $\begin{array}{l}\text { At what point would you consider water resources in the basin } \\
\text { to be in a critical situation? }\end{array}$ & $\begin{array}{c}2013 \\
n=100\end{array}$ & $\begin{array}{c}2014 \\
n=100\end{array}$ & $\begin{array}{c}2015 \\
n=100\end{array}$ \\
\hline The basin is already in crisis & $23 \%$ & $36 \%$ & $47 \%$ \\
\hline Any increase in pumping & $24 \%$ & $29 \%$ & $19 \%$ \\
\hline Year 2000 pumping rates & $27 \%$ & $16 \%$ & $13 \%$ \\
\hline Above the $1 \%$ rate set by the Groundwater Plan & $20 \%$ & $16 \%$ & $21 \%$ \\
\hline Increased pumping is not a crisis & $6 \%$ & $4 \%$ & $0 \%$ \\
\hline $\begin{array}{l}\text { Is it important to take a regional, collaborative approach among } \\
\text { governments, agencies and stakeholders to address water } \\
\text { resource issues? }\end{array}$ & $\begin{array}{c}2013 \\
n=100\end{array}$ & $\begin{array}{c}2014 \\
n=100\end{array}$ & $\begin{array}{c}2015 \\
n=100\end{array}$ \\
\hline Strongly Agree & $\mathrm{N} / \mathrm{A}$ & $\mathrm{N} / \mathrm{A}$ & $93 \%$ \\
\hline Agree & $\mathrm{N} / \mathrm{A}$ & $\mathrm{N} / \mathrm{A}$ & $7 \%$ \\
\hline Neutral & $\mathrm{N} / \mathrm{A}$ & $\mathrm{N} / \mathrm{A}$ & $0 \%$ \\
\hline Disagree & $\mathrm{N} / \mathrm{A}$ & $\mathrm{N} / \mathrm{A}$ & $0 \%$ \\
\hline Strongly Disagree & $\mathrm{N} / \mathrm{A}$ & $\mathrm{N} / \mathrm{A}$ & $0 \%$ \\
\hline
\end{tabular}


Table 4. Cont.

\begin{tabular}{cccc}
\hline Is the development of a reclaimed water plant in Pullman & $\mathbf{2 0 1 3}$ & $\mathbf{2 0 1 4}$ & $\mathbf{2 0 1 5}$ \\
a priority? & $\mathbf{n = 1 0 0}$ & $\mathbf{n = 1 0 0}$ & $\boldsymbol{n}=\mathbf{1 0 0}$ \\
\hline The completion of this plant is a high priority & $87 \%$ & $91 \%$ & $94 \%$ \\
This plant is a waste of money & $3 \%$ & $4 \%$ & $6 \%$ \\
I have no opinion & $10 \%$ & $4 \%$ & $0 \%$ \\
\hline As an individual water consumer on the Palouse what are you & $\mathbf{2 0 1 3}$ & $\mathbf{2 0 1 4}$ & $\mathbf{2 0 1 5}$ \\
going to do in the coming year? & $\boldsymbol{n}=\mathbf{1 0 0}$ & $\mathbf{n = 1 0 0}$ & $\boldsymbol{n}=\mathbf{1 0 0}$ \\
\hline Reducing my indoor water use by changing out fixtures & $\mathrm{N} / \mathrm{A}$ & $\mathrm{N} / \mathrm{A}$ & $12 \%$ \\
Change my personal water behavior & $\mathrm{N} / \mathrm{A}$ & $\mathrm{N} / \mathrm{A}$ & $23 \%$ \\
Talk to friends and neighbors about water & $\mathrm{N} / \mathrm{A}$ & $\mathrm{N} / \mathrm{A}$ & $12 \%$ \\
Get involved in education and outreach & $\mathrm{N} / \mathrm{A}$ & $\mathrm{N} / \mathrm{A}$ & $27 \%$ \\
Make my home $/$ Nusiness landscaping an example of low water use & $\mathrm{N} / \mathrm{A}$ & $\mathrm{N} / \mathrm{A}$ & $26 \%$ \\
\hline
\end{tabular}

Table 5. Partial list of responses to clicker questions presented to participants at the Spokane River Forum in 2011, 2013 and 2014 (for additional questions please contact authors).

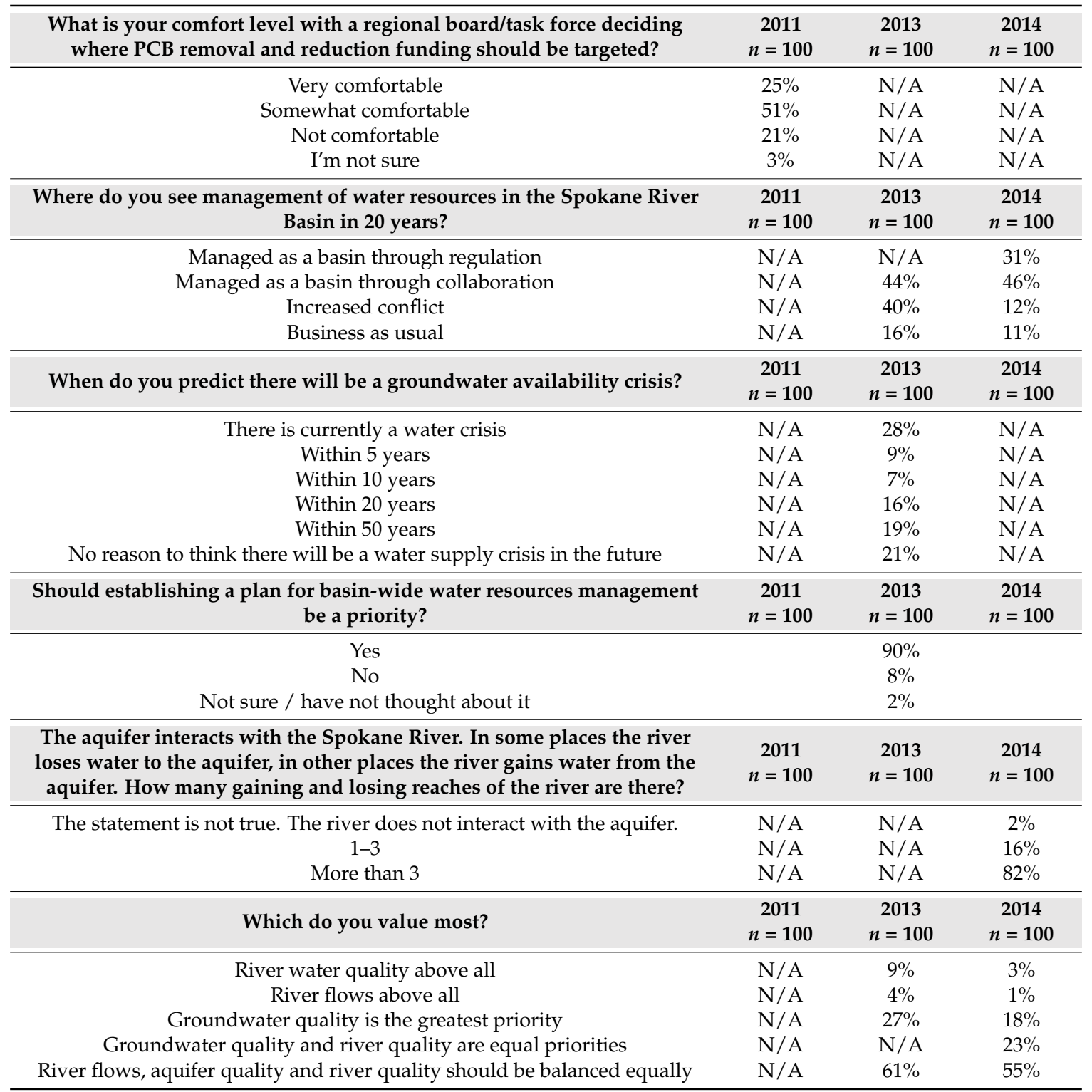




\subsection{Building Simulations}

In conjunction with the initial and ongoing stakeholder engagement activities, stakeholders were involved in the model building and model simulation phases. In the Palouse Basin, Stella [73] systems modeling software was used for simulation. In the Spokane basin, OASIS [74] linear programming model was used for simulation. The development of simulation models to explore future changes to water resources enables stakeholders to share insights into potential solutions to better understand and or manage their local water resource system. Iterations over time are necessary to develop robust models that incorporate the complexities of water resource systems. Iteration provides opportunity to clearly communicate assumptions and uncertainties and to test sensitivity and policies (Figure 1b).

In 2008, collaborators began a model building exercise in the Palouse Basin resulting in the 2010 version of the Palouse Basin Water Resource Visioning Tool that integrated current scientific understanding of the aquifer system and a suite of options for simulating growth, conservation and supply augmentation [53]. The model was built with system dynamics theory and Stella software. We chose to use Stella, because of its module and storytelling features. Modules were used to separate the structures for each aquifer, demand and potential new supplies so as to more easily display these structures to stakeholders. The story telling feature was integrated into the online version of the tool to allow users to click through model structures that, when supported with pop up text boxes, explain how supply is determined. The online version utilizes NetSim software and is housed on a publically available Forio server [75]. During the two year model development process, we met every month to six weeks with four to eight representatives from the Palouse Basin Aquifer Committee (PBAC) and two to six members of the interested public. Between meetings the lead modeler met individually with hydrogeologic experts from University of Idaho, Washington State University and Washington Department of Ecology to develop consensus on model structure, assumptions and uncertainty. The latest iteration of the model includes hypothetical groundwater dynamics (data is limited), historic pumping data, projected future demand under user varied growth and conservation scenarios, individual water use calculator, the opportunity to add three different reservoir sizes to augment supply, and information on basin hydrogeology and model assumptions [75].

In the Spokane basin, the model building process began in 2013. The trust we built in the 2008-2010 with Inland Northwest hydrogeologic experts during the Palouse project was instrumental in the acceptance of this process. Unlike the Palouse, the Spokane system has abundant data, an extensive network of monitoring wells, and a USGS MODFLOW model. We approached stakeholders with the idea of using this information to create a dynamically integrated ground and surface water model that could be used as a collaborative planning tool in, for what would initially be, a mock planning process. The model has been built using OASIS HydroLogics software that uses a fully configurable linear programming solver to simulate water routing and optimize system operations on a daily time step [74]. Individual and small group meetings took place monthly over the course of two years between researchers and experts from Washington State University, Washington Department of Ecology, Idaho Washington Aquifer Collaborative, and Spokane and Kootenai Counties. The collaboratively built model includes surface and groundwater dynamics, and a suite of stakeholder relevant issues that include growth, conservation, and climate change. The model simulates a range of potential impacts to the hydrologic system, including changes to lake levels during the summer or violation of the minimum instream flow rule. Through this process, participants have the ability to suggest simulation of alternative strategies or scenarios. The capacity to quickly modify parameters for new scenarios provides stakeholders with immediate feedback about their perspectives, ideas and concerns [76].

\section{Collaborative Modeling in Action}

\subsection{Regional Water Conferences: Using Clicker Surveys to Understand Group Mental Models}

Regional water conferences provided an opportunity to anonymously survey an audience to better understand participant's knowledge of basic water science, values, preferences and priorities 
on water management challenges. The collaborative development of these questions and the use of clickers at the conference is a useful exercise for exploring mental models of both individuals and groups of people interested in their local water resources. Over time, we have had the opportunity to iterate useful, illuminating questions and to remove questions that offer little insight. Each water conference used the clickers and developed questions that were relevant to current water resource challenges in each basin. Tables 4 and 5 provide results from a limited number of clicker questions to highlight insights from these sessions.

\subsubsection{Palouse Water Summit}

In the Palouse basin, conference participants answered questions on hydrology basics, preferences on infrastructure development and local water management in 2013, 2014 and 2015. Answers to the questions on basic water science indicate that individuals understand that growth and increase in water demand are not linear, and that water levels are dependent on multiple internal (aquifer properties) and external (pumping) factors. Participants indicate that there is significant interest in the City of Pullman and WSU moving forward with a proposed reclamation plant that will supply irrigation water for landscaping on campus (Table 4). Participants were also asked where they viewed water resource management in 20 years. Summit attendees increasingly have the opinion that the basin is already in crisis, however they also value bi-state cooperation (Table 4). In addition, participants have consistently preferred increased collaboration and cooperation, rather than a formal bi-state agreement or increased conflict (Table 4). Participants are indicating a willingness to proactively communicate information about the resource to others in the community and to make a personal effort to conserve (Table 4).

These sessions spark discussion among participants that often continue post Summit [76]. Individuals are able to grasp how well others understand a system and or feel about its future, which helps individuals evaluate how and why people are behaving and making choices. Based on individual stakeholder meetings and collaboratively developing the Summit questions, it appears that there are at least two categories of mental models that stakeholders view as a potential source of conflict. Some individuals believe "we have lots of water, so why worry about it", and "when there is a problem, they [future generations] can pay for it." Others believe "we need to conserve more water now", and "the big four pumpers are using water unsustainably, they need to change use immediately." The "we have plenty of water" versus "conserve more now" mental models often become part of the "pro development" versus "limit development" conversation. While pro development contingents are not promoting high water demand industry, there is a significant contingent of people who indicate that conservation should be a high priority. Many of the pro conservation people also value limited development.

While collaboration across state lines is supported, the potential for conflict over values, growth and water for future generations is resulting in creative tension. With no immediately imminent supply crisis, the tension over limited future supply and the sense that the basin is already in crisis is driving not only conservation of water resources, but also the desire for proactive exploration into alternative infrastructure developments to support a sustainable future. The Palouse Basin Aquifer Committee has utilized state funds to support a study to explore multiple types of augmentation including aquifer storage and recovery, reservoirs and reuse with a potential target for implementation in the 2020s [50,77].

\subsubsection{Spokane River Forum}

In the Spokane Basin, conference participants used clickers at the 2011, 2013 and 2014 Forums to answer questions related to education, perceptions, values and priorities. In 2011, the focus on the clicker questions was related to potential future collaboration on a PCB TMDL and the potential for collaborative basin wide management (Table 5). As we approached the end of the session in 2011, people were beginning to look around at one another with quizzical expressions. Based on data that 
included answers to questions such as level of comfort for a regional board deciding where PCB removal and reduction should be targeted, and post session discussion, we discovered that people were very surprised at the degree of consensus in the room. To continue to support and promote collaboration across state lines, at subsequent Forums questions were asked about the interest for collaborative bi-state water resource management. Responses related to collaborative bi-state water resources management indicate the level of interest is high (Table 5). The decision to not continue a question related to crisis was driven by the organizer's value for emphasizing collaboration over crisis.

At the end of the 2013 Forum, conference participants answered questions on basic water science. We found that there was a significant level of misunderstanding about the aquifer and how it interacted with the river, even though there were two days of presentations on aquifer science, hydrologic research and policy questions based on hydrology. As a result, conference organizers changed strategy at the next Forum held in 2014, and held a plenary session on "hydrology 101" early on the first day. While the number of participants indicating that there were at least 3 gaining and losing reaches in the river was high this type of question provided the opportunity for the panel to reinforce river-aquifer interaction. Additionally at both the 2013 and 2014 Forums, conference participants answered questions on water availability, their values on water, and collaboration (Table 5).

Questions are tailored for the specific topic of the Forum therefore questions are not consistent across time. The most prominent mental model that has surfaced at the Forums is the desire for basin wide collaborative management. The final panel session at the 2014 Forum included state agency leads, tribal representatives and a local environmental attorney. The discussion highlighted the recognition that this basin could collaborate on difficult issues and that this value should be integrated into the training of next generation of managers. As collaborative modelers we recognize that this desire to collaborate is the result of multiple factors however using clicker sessions to intentionally recognize the number of people who value collaboration helps build confidence in the possibilities that collaboration brings.

\subsection{Building Computer Simulations: Dialogue and Insights}

The collaborative modeling process has provided the opportunity for model building and facilitated group problem solving to take place simultaneously [53,76]. In these individual and group meetings, stakeholders have continuously been encouraged to communicate their own values, interests and knowledge of the system, and willingly have been active participants in discussion. These lively discussions have been important to incorporating stakeholder's interests into the model.

\subsubsection{Development of the Palouse Basin Water Resource Visioning Tool}

During the two-year CM process our discussions often included issues associated with scientific uncertainty and needed research. One manager asked how we "could create a model without more information." This experienced manager had a mental model of how the system would respond to pumping over the long term; however, he conveyed that communicating that experience was challenging. The model and CM process created an opportunity for managers to communicate their mental models to one another and to communicate to model users the level of scientific uncertainty under which managers made decisions. Political sensitivity and the manner in which the model portrayed information were of concern. For example, well levels were described graphically as feet above mean sea level, yet depending upon the scale, there was concern by several stakeholders that the model may indicate that the "basin was running out of water". Many of the graphical interfaces were iterated multiple times in response to this concern. The potential impacts of population growth on future demand were also of political concern. The model utilizes per capita use and has the option for users to choose population growth rates. During a presentation to the entirety of PBAC, one stakeholder stated that we "could not talk about development", again indicating the concern about pro growth versus the no growth mental models in the basin. Stakeholders have stated that lack of imminent supply crisis, and the concern about scientific uncertainty and sensitive political 
relationships has prevented the use of this tool for planning. With this in mind, the interface was designed primarily as an education and outreach tool, however an interface suitable for technicalities related to planning could be added at any time $[53,75]$. The tool has been used extensively as an educational tool for university students, who comprise almost half of the population of the basin. Since its launch in May 2010, at least 3500 WSU students have utilized the model for aquifer education and as a water footprint calculator.

Additional well data, interest in potential new supply, and requests for revision of the model interface are leading to a major revision of the tool that is taking place in 2016-2017. Familiarity with the modeling platform and the long-term relationships we have built in the basin is expediting the CM process and should expand the model scope and usefulness.

\subsubsection{Development of the Spokane River Basin OASIS}

The ongoing collaborative modeling process has been iterative and is deepening understanding of the complex dynamic interaction of the surface and groundwater systems in the region in the context of climate change and increasing demand [76]. We have often returned to discussions that focus on identifying and defining the regional water resource problem, a valuable step in the systems thinking to policy development process. There has been lengthy dialogue about the complexity of interactions between surface and groundwater at different reaches along the Spokane River. At times, stakeholder perspectives and knowledge about ground-surface water interaction have been conflicting and or dissimilar. For example, most stakeholders generally agree that groundwater pumping impacts streamflow, but during one discussion, a stakeholder stated "groundwater pumping does not impact flows in the river." This particular circumstance was met as an opportunity to build consensus. We asked stakeholders to teach us about their system to be better reflected it in the model. Stakeholders clarified their scientific understanding and related assumptions about the integrated surface and groundwater system. Although some have said that pumping did not impact streamflow, in general, we found the issue had more to do with current pumping rates than the issue itself. This non-confrontational manner of facilitating discussion diverted a potentially divisive moment. We have observed through these types of facilitated discussions, that stakeholders realize there is significant scientific consensus and that disagreements may often be the result of semantics. We observe that this consensus is helping to build trust among bi-state stakeholders.

\section{Discussion}

\subsection{Benefits of Collaborative Modeling before Conflict or as a Pre-Planning Tool}

Water resource managers, in both the Spokane and the Palouse, have stated that they know that tough decisions will have to be made in the future. They have stated that providing the opportunity for discussion, in advance of the need for a specific, potentially legally binding decision, opens up opportunity for critical and creative thinking. They have repeatedly made requests for us "to help keep the conversation going" because as systems leaders they understand the value of conversation for education, outreach and for shifting entrenched mental models. As modelers outside of the decision-making framework, we are able to facilitate exploration that may include options that are not possible in current regulatory regimes. For example, in the Spokane basin we are able to explore what if the system was not constrained by the current FERC license. While we are not advocating that the licensing process was problematic, we do want to offer a full suite of potential management options for exploration as we help basin stakeholders plan for the unthinkable, such as an extended drought. In the Palouse basin, we included the option for reservoirs in Idaho to augment supply in the entire basin. Delivering water across state lines is not possible under the current regulatory framework. Stakeholders are enthusiastic about having these options available, however they may be reluctant to bring them forward while representing their respective entities. Pre-conflict, pre-decision simulation and gaming exercises provides a space where no option is "off the table", or where no particular set of 
values takes precedent, and in doing so facilitates the creative tension between what was or is and what could be.

The development of clicker sessions that pose questions from "stakeholders to stakeholders" (through the modeling team) illuminates mental models and assumptions of individuals, as well as their perception of what others may value. Question development with basin stakeholders offers individuals the opportunity to think about the greater system. For example, at the end of a question development meeting, a wastewater plant manager thanked us for the opportunity to think beyond the operation of "pumps, pipes and the regulation of effluent for water quality" to the production and impact of wastewater on the greater system. His view of the greater system included fisheries and recreation; the value that people place on household products and the risk assessment process they use to make choices about those products; the economic legacy of the area that includes impacts from agriculture, timber, mining, aluminum foundries; and finally a vision of how today's legacy will be viewed in the future. Opportunities such as this support individual system thinking investments and help advance mental models well beyond typical daily activities.

As preferences of groups of people are revealed through the clickers, group mental models are supported. For example, although conflict in the Palouse basin has been fairly limited, clicker results consistently indicate that the potential for conflict is high, any increase in pumping is not acceptable, and any increase in growth would necessitate large changes in supply infrastructure. The group mental model "we need to do something soon, and do it together" is supporting system leaders in the Palouse as they explore a diverse array of supply augmentation strategies [77].

Clicker sessions in the Spokane have continually reinforced the value that people place on collaboration and the value that people place on leaving a legacy of collaboration in their respective agencies and organizations. Additionally, we are finding that this desire to collaborate is altering how water professionals and purveyors view the public they serve. For example, we have been facilitating informal collaborative modeling workshops with a group of water resources professionals from both Idaho and Washington with the intent of developing future scenarios. The long term purpose of these discussions is to develop future planning scenarios relevant to managers, however focus within this group has in the short term shifted to public perception, awareness and understanding of local water supply. This apparent deviation from scenario development reflects the sensitivity that managers have for developing scenarios for what they describe as an "unsuspecting" public. They have stated that it is "difficult to justify the importance of conservation to a public who perceives the water supply as endless." Educating the public is now a central focus for this group. While some may consider that our CM scenario development process was side tracked, we view this as an opportunity to explore perceptions about public tolerance for potential policies. Additionally, this reinforces the concept that all water users are decision makers. Our long-term investment with this basin offers us this important opportunity, even though the time-table for model scenario development has been disrupted.

When we first began visiting stakeholders in the Spokane basin, we were told "Idaho did not have a supply or quality problem, it has a Washington problem." While these issues are certainly not completely resolved, it is now rare to hear about them when working with stakeholders. We are now able to include future scenarios that include growth, conservation, and climate change. We are able to include potential decisions about these issues that are not state or community specific. Finally, we are hearing stakeholders make statements including "lets think about potential solutions for supply augmentation" in the Palouse basin and "how can we get the public on board with conservation" in the Spokane basin.

\subsection{Challenges of Pre-Conflict Collaborative Modeling}

Participatory processes have many benefits that engage stakeholders, however it is often challenging to continuously encourage stakeholder participation, manage expectations of stakeholders and scientists and effectively communicate among stakeholders. Stakeholder participation and modeling is time consuming, and the quality of work is dependent on the quality of available data, the 
techniques and skills of the facilitators and modelers, and the willingness of the stakeholders to work together to find potentially mutually beneficial solutions $[37,43]$. Stakeholders are often volunteers, attendance may be inconsistent, and the composition of the group may change over time. It is difficult to encourage stakeholders to actively participate and maintain interest throughout the timespan of the project when there is not an active crisis or a decision to be made. Absence of mutual trust among stakeholders can hinder effective participation during the participatory process [43]. Participants may not be willing to change their mental models, and they may have personal objectives that reduce their willingness to change their opinions. However, both of the participatory process in each of these basins has allowed for ongoing communication of stakeholders and scientific information. The continued communication among stakeholders has been crucial in each basin.

Another challenge that is faced, in many if not all collaborative modeling processes is measuring success. Even in processes that have resulted in a specific decision, long-term success is not guaranteed. In the absence of a specific decision, we are left with a qualitative assessment of success that is potentially biased by those whose mental models are supported. However, even in the absence of empirical evidence, we argue in support of the ideals that resulted in NEPA and the inclusion of adaptive management principles in natural resource management. Discussion that includes social and ecological values, and integrates best available science increases the likelihood of outcomes that support adaptive and resilient social and ecological systems.

\section{Conclusions}

These case studies focus on the value of collaborative modeling processes prior to crisis driven decision-making. System leaders in both basins realize that conversation and education in advance of crisis builds relationships and trust. In both of the Palouse and Spokane systems, CM has helped facilitate collaboration and improved group dynamics, and it has created space for exploring the dynamic problem, potential futures and potential opportunities for improving long-term resilience. Throughout the simulation model building process in both basins, we have found that there is an increasing willingness to discuss, and model what can be divisive topics such as climate change, growth or scientific uncertainty. We are hopeful by supporting stakeholders within a pre conflict exploratory space that resilient governance will be discovered and designed.

The need for adaptive and resilient water resource management and governance is challenging resource managers and water users to think about their resources in context of highly integrated systems. Issues such as increasing demand, decreasing quality, development, storm water, runoff, as well as unanticipated feedbacks, time delays, changing weather patterns, and changing social values are characteristics that these integrated systems often share. As we learn to do adaptive management in these systems, it is easy to get caught in the minutia of the task at hand and lose sight of the integrated system. Entrenchment in a single part of the system or in mental models that only reflect the past have the potential to restrict the creative space needed for adaptation, and in so doing increases potential for conflict. It is also important to understand that we are all trying to design governance for which no blueprint exists and that policies that may work in one basin may not necessarily work in another basin. Finally, our stakeholders have often said that we must realize that we never solve all of our problems and challenges, we just move from solution to the next challenge. Throughout this process, maintaining relationships is critical.

As collaborative modelers, we seek to support our stakeholders and their communities, through opportunities for ongoing, iterative systems research, education and outreach. Supporting system thinking investment within iterative decision processes improves the capability for spanning institutional, cultural, spatial and or temporal boundaries, and simultaneously improves the potential for adaptive and resilient water resource governance within constantly changing social and biophysical systems. 
Acknowledgments: Acknowledgement to USDA National Institute of Food and Agriculture, Spokane River Forum, Palouse Basin Water Summit and all of the stakeholders in the Palouse and Spokane Basins from whom we have learned so much.

Author Contributions: Author Beall King conceived of the collaborative modeling projects in the Palouse and Spokane basins and has been lead on the exercises described in this paper with co-author Thornton often serving as co-facilitator (2013-present). Author Thornton built the OASIS model described herein and is lead facilitator for the Spokane basin OASIS exercise. Beall King and Thornton collaborated on the text of this paper.

Conflicts of Interest: The authors declare no conflict of interest.

\section{References}

1. Walker, B.; Holling, C. Resilience, adaptability and transformability in social-Ecological systems. Ecol. Soc. 2004, 9, 5 .

2. Holling, C.S. Adaptive Environmental Assessment and Management; John Wiley \& Sons: Chichester, UK, 1978.

3. Cortner, H.; Moote, M. Trends and issues in land and water resources management: Setting the agenda for change. Environ. Manag. 1994, 18, 167-173. [CrossRef]

4. Pahl-Wostl, C.; Craps, M. Social learning and water resources management. Ecol. Soc. 2007, 12, 2007.

5. Kallis, G.; Videira, N.; Antunes, P. Participatory methods for water resources planning. Environ. Plan. C Gov. Policy 2006, 24, 215-234. [CrossRef]

6. Crutzen, P. Geology of mankind. Nature 2002, 415, 23. [CrossRef] [PubMed]

7. National Environmental Policy Act (NEPA); 42 U.S. Code §4321; United States Federal Government: Washington, DC, USA, 1969.

8. Clean Air Act (CAA); 42 U.S. Code §§7241-7671; United States Federal Government: Washington, DC, USA, 1970.

9. Clean Water Act (CWA); 33 U.S. Code §§1251-1387; United States Federal Government: Washington, DC, USA, 1972.

10. Endangered Species Act (ESA); 16 U.S. Code §§1531-1544; United States Federal Government: Washington, DC, USA, 1973.

11. Hardin, G. The tragedy of the commons. Science 1968, 162, 1243-1248. [CrossRef] [PubMed]

12. Beall, A.M. Participatory Environmental Modeling and System Dynamics: Integrating Natural Resource Science and Social Concerns. Ph.D. Thesis, Washington State University, Pullman, WA, USA, 2007.

13. Guttman, N. Bringing the mountain to the public: Dilemmas and contradictions in the procedures of public deliberation initiatives that aim to get "ordinary citizens" to deliberate policy issues. Commun. Theory 2007, 17, 411-438. [CrossRef]

14. Reed, M.S. Stakeholder participation for environmental management: A literature review. Biol. Conserv. 2008, 141, 2417-2431. [CrossRef]

15. O'Leary, R.; Bingham, L.B. The Promise and Performance of Environmental Conflict Resolution; RFF Press: New York, NY, USA, 2003.

16. Dietz, T.; van den Belt, M. Forward. In Mediated Modeling; Island Press: Washington, DC, USA, $2004 ;$ p. xiii.

17. Grumbine, R.E. What Is Ecosystem Management? Conserv. Biol. 1994, 8, 27-38. [CrossRef]

18. Nagle, J.; Ruhl, J. The Law of Biodiversity and Ecosystem Management; Foundation Press: New York, NY, USA, 2002.

19. Folke, C. Resilience: The emergence of a perspective for social-ecological systems analyses. Glob. Environ. Chang. 2006, 16, 253-257. [CrossRef]

20. Millennium Ecosystem Assessment. Available online: http://www.millenniumassessment.org/en/index. html (accessed on 15 May 2016).

21. Global Watership Partnership Technical Advisory Committee. Integrated Water Resources Management; TAC Background Paper; Global Water Partnership: Stockholm, Sweden, 2000.

22. Dörendahl, E.I. Boundary Work and Water Resources: Towards Improved Management and Research Practice?; ZEF Working Paper Series, No. 122; Zentrum für Entwicklungsforschung: Bonn, Germany, 2013.

23. Liu, Y.; Gupta, H.; Springer, E.; Wagener, T. Linking science with environmental decision making: Experiences from an integrated modeling approach to supporting sustainable water resources management. Environ. Model. 2008, 23, 846-858. [CrossRef] 
24. Jacobs, K. Connecting Science, Policy, and Decision-Making: A Handbook for Researchers and Science Agencies; NOAA Office of Global Programs; NOAA Climate Diagnostics Center: Boulder, CO, USA, 2002.

25. Beall, A.; Ford, A. Reports from the Field: Assessing the Art and Science of Participatory Environmental Modeling. Int. J. Inf. Syst. Soc. Chang. 2010, 1, 72-89. [CrossRef]

26. Bourget, E.C.; Langsdale, S.M.; van den Belt, M. Featured Collection Introduction: Collaborative Modeling for Decision Support as a Tool to Implement IWRM. J. Am. Water Resour. Assoc. 2013, 49, 605-608. [CrossRef]

27. Meadows, D.; Robinson, J. The Electronic Oracle; System Dynamics Society: Albany, NY, USA, 1985.

28. Perez, E.M.; Viessman, W. The Role of Technology in Water Resources Planning and Management; Brown \& Caldwell: West Palm Beach, FL, USA, 2009.

29. Voinov, A.; Bousquet, F. Modelling with stakeholders. Environ. Model. Softw. 2010, 25, 1268-1281. [CrossRef]

30. Winz, I.; Brierley, G.; Trowsdale, S. The use of system dynamics simulation in water resources management. Water Resour. Manag. 2009, 23, 1301-1323. [CrossRef]

31. Voinov, A.; Gaddis, E.J.B. Lessons for successful participatory watershed modeling: A perspective from modeling practitioners. Ecol. Model. 2008, 216, 197-207. [CrossRef]

32. Ford, A. Modeling the Environment: An Introduction to System Dynamics Modeling of Environmental Systems, 2nd ed.; Island Press: Washington, DC, USA, 2009.

33. Johnson-Laird, P. Mental models in cognitive science. Cogn. Sci. 1980, 4, 71-115. [CrossRef]

34. Senge, P. The Fifth Discipline: The Art and Practice of the Learning Organization; Double Day: New York, NY, USA, 1990.

35. Vennix, J.A.M. Group Model Building: Facilitating Team Learning Using System Dynamics; Wiley: Chichester, UK, 1996.

36. Richmond, B.; Peterson, S. An Introduction to Systems Thinking; High Performance Systems: Hanover, NH, USA, 2001.

37. Bourget, L. Converging Waters: Integrating Collaborative Modeling with Participatory Processes to Make Water Resources Decisions; Bourget, L., Ed.; Institute for Water Resources: Alexandria, VA, USA, 2011.

38. Parson, E. Integrated assessment and environmental policy making: In pursuit of usefulness. Energy Policy 1995, 23, 463-475. [CrossRef]

39. Cardwell, H.; Langsdale, S.; Stephenson, K. The Shared Vision Planning Primer: How to Incorporate Computer Aided Dispute Resolution in Water Resources Planning; Institute for Water Resources: Alexandria, VA, USA, 2008.

40. Costanza, R.; Ruth, M. Using dynamic modeling to scope environmental problems and build consensus. Environ. Manag. 1998, 22, 183-195. [CrossRef]

41. Cardwell, H.E.; Langsdale, S. Collaborative Modeling for Decision Support-Definitions and Next Steps. In Proceedings of the World Environmental and Water Resources Congress; Beighley, R., II, Kilgore, M., Eds.; ASCE: Reston, VA, USA, 2011; pp. 2805-2814.

42. Van den Belt, M. Mediated Modeling: A System Dynamics Approach to Environmental Consensus Building; Island Press: Washington, DC, USA, 2004.

43. Langsdale, S.; Beall, A.; Bourget, E.; Hagen, E.; Kudlas, S.; Palmer, R.; Tate, D.; Werick, W. Collaborative Modeling for Decision Support in Water Resources: Principles and Best Practices. J. Am. Water Resour. Assoc. 2013, 49, 629-638. [CrossRef]

44. Videira, N.; Antunes, P. Participatory modelling in environmental decision-making: The ria Formosa natural park case study. J. Environ. Assess. Policy Manag. 2003, 5, 421-447. [CrossRef]

45. Cockerill, K.; Passell, H.; Tidwell, V. Cooperative Modeling: Building bridges between science and the public. J. Am. Water Resour. Assoc. 2006, 42, 457-471. [CrossRef]

46. Creighton, J. How to Conduct a Shared Vision Planning Process; IWR Report 10-R-6; U.S. Army Institute for Water Resources: Alexandria, VA, USA, 2010.

47. Lund, J.; Palmer, R. Water resource system modeling for conflict resolution. Water Resour. Update 1997, 3, 70-82.

48. Langsdale, S.; Beall, A.; Carmichael, J.; Cohen, S.; Forster, C.; Neale, T. Exploring the implications of climate change on water resources through participatory modeling: Case study of the Okanagan Basin, British Columbia. J. Water Resour. Plan. Manag. 2009, 135, 373-381. [CrossRef]

49. Sheer, D.P.; Baeck, M.L.; Wright, J.R. Computer as negotiator. J. Am. Water Work. Assoc. 1989, 81, 68-73.

50. Palouse Basin Aquifer Committee (PBAC). Available online: http://www.webpages.uidaho.edu/pbac/ (accessed on 15 January 2016).

51. Leek, F. Hydrogeological Characterization of the Palouse Basin Basalt Aquifer System. Master's Thesis, Washington State University, Pullman, WA, USA, 2006. 
52. Kahle, S.; Bartolino, J. Hydrogeologic Framework and Ground-Water Budget of the Spokane Valley-Rathdrum Prairie Aquifer, Spokane County, Washington, and Bonner and Kootenai Counties, Idaho; U.S. Geological Survey Scientific Investigations Report; USGS: Reston, VA, USA, 2007.

53. Beall, A.; Fiedler, F.; Boll, J.; Cosens, B. Sustainable water resource management and participatory system dynamics. Case study: Developing the Palouse basin participatory model. Sustainability 2011, 3, 720-742. [CrossRef]

54. Smoot, J.; Ralston, D. Hydrogeology and a Mathematical Model of Ground-Water Flow in the Pullman-Moscow Region, Washington and Idaho; Idaho Water Resources Research Institute: Moscow, ID, USA, 1987.

55. Luce, C.; Abatzoglou, J.; Holden, Z. The missing mountain water: Slower westerlies decrease orographic enhancement in the Pacific Northwest USA. Science 2013, 342, 1360-1364. [CrossRef] [PubMed]

56. Dunau, A.; Spokane River Forum, Spokane, WA, USA. Personal communication, 2009-2016.

57. Idaho Washington Aquifer Collaborative (IWAC). Available online: http://www.iwac.us (accessed on 16 February 2016).

58. Fu, G.; Barber, M.; Chen, S. Impacts of climate change on regional hydrological regimes in the Spokane River Watershed. J. Hydrol. Eng. 2007, 12, 452-461. [CrossRef]

59. Hsieh, P.; Barber, M.; Contor, B. Ground-Water Flow Model for the Spokane Valley-Rathdrum Prairie Aquifer, Spokane County, Washington, and Bonner and Kootenai Counties, Idaho; U.S. Geological Survey Scientific Investigations Report; USGS: Reston, VA, USA, 2007.

60. Molenaar, D. The Spokane Aquifer, Washington: Its Geologic Origin and Water-Bearing and Water-Quality Characteristics; U.S. Geological Survey Scientific Investigations Report; USGS: Reston, VA, USA, 1988.

61. Washington Department of Ecology. Water Resource Program: Rulemaking. Available online: http://www. ecy.wa.gov/programs/wr/rules/557-ov.html (accessed on 16 February 2016).

62. Washington Department of Ecology Water Quality Improvement Project Spokane River and Lake Spokane Area: Dissolved Oxygen. Available online: http://www.ecy.wa.gov/PROGRAMS/wq/tmdl/spokaneriver/ dissolved_oxygen/index.html (accessed on 16 February 2016).

63. Stave, K. Using system dynamics to improve public participation in environmental decisions. Syst. Dyn. Rev. 2002, 18, 139-167. [CrossRef]

64. Vennix, J.A.M.; Andersen, D.F.; Richardson, G.P. Foreword: Group model building, art, and science. Syst. Dyn. Rev. 1997, 13, 103-106. [CrossRef]

65. Andersen, D.F.; Richardson, G.P.; Vennix, J.A.M. Group model building: Adding more science to the craft. Syst. Dyn. Rev. 1997, 13, 187-201. [CrossRef]

66. Rivera, M.W.; Sheer, D.P.; Miller, A.J. Computer-Aided Negotiations of Water Disputes: An Interdisciplinary Role-Playing Course. J. Am. Water Resour. Assoc. 2013, 49, 700-714. [CrossRef]

67. Forrester, J. System dynamics, systems thinking and soft OR. Syst. Dyn. Rev. 1994, 10, 245-256. [CrossRef]

68. Meadows, D.; Wright, D. Thinking in Systems: A Primer; Chelsea Green Publishing: Danvers, MA, USA, 2008.

69. Mott Lacroix, K.; Megdal, S. Explore, Synthesize, and Repeat: Unraveling Complex Water Management Issues through the Stakeholder Engagement Wheel. Water 2016, 8. [CrossRef]

70. Palouse Basin Water Summit. Available online: http://www.palousewatersummit.org/ (accessed on 12 December 2015).

71. Spokane River Forum. Available online: http:/ / spokaneriver.net (accessed on 12 December 2015).

72. Stowell, J.; Nelson, J. Benefits of electronic audience response systems on student participation, learning, and emotion. Teach. Psychol. 2007, 34, 253-258. [CrossRef]

73. Stella Systems Modeling Software; ISEE Systems Inc.: Lebanon, NH, USA, 2005.

74. Hydrologics Inc. User Manual for OASIS with OCL; Hydrologics Inc.: Columbia, MD, USA, 2009.

75. Beall, A. The Palouse Basin Water Resource Visioning Tool. Available online: http://forio.com/simulation/ ns/allysonbeall/palouse_basin_model/ (accessed on 18 February 2016).

76. Thornton, M. Washington State University: Pullman, WA, USA, 2017. Unpublished Work.

77. Kimmell, P.; Palouse Basin Aquifer Committee, Latah County, ID, USA. Personal Communication, 2013-2015.

(C) 2016 by the authors; licensee MDPI, Basel, Switzerland. This article is an open access article distributed under the terms and conditions of the Creative Commons Attribution (CC-BY) license (http://creativecommons.org/licenses/by/4.0/). 